\title{
A new perspective on life-saving procedures in a battlefield setting: Emergency cricothyroidotomy, needle thoracostomy, and chest tube thoracostomy with night vision goggles
}

\author{
Sedat Bilge, M.D., ${ }^{1}$ Attila Aydın, M.D., ${ }^{1}$ Meltem Bilge, M.D., ${ }^{3}$ Cemile Aydın, M.D., ${ }^{4}$ \\ Erdem Çevik, M.D., ${ }^{2}$ Mehmet Eryılmaz, M.D. ${ }^{1}$

\begin{abstract}
'Department of Emergency Medicine, Gülhane Training and Research Hospital, Ankara-Turkey
${ }^{2}$ Department of Emergency Medicine, Sultan Abdülhamit Training and Research Hospital, İstanbul-Turkey

${ }^{3}$ Department of Anesthesiology and Reanimation, Dışkapı Training and Research Hospital, Ankara-Turkey

${ }^{4}$ Department of Internal Medicine, Ankara Etimesgut State Hospital, Ankara-Turkey
\end{abstract}

\begin{abstract}
BACKGROUND: In the patients with multiple and serious trauma, early applications of life-saving procedures are related to improved survival. We tried to experimentally determine the feasibility of life-saving interventions that are performed with the aid of night vision goggles (NVG) in nighttime combat scenario.

METHODS: Chest tube thoracostomy (CTT), emergency cricothyroidotomy (EC), and needle thoracostomy (NT) interventions were performed by 10 combatant medical staff. The success and duration of interventions were explored in the study. Procedures were performed on the formerly prepared manikins/models in a bright room and in a dark room with the aid of NVG. Operators graded the ease of interventions.
\end{abstract}

RESULTS: All interventions were found successful. Operators stated that both CTT and EC interventions were more difficult in dark than in daytime $(p<0.05)$. No significant difference was observed in the difficulty in the NT interventions. No significant difference was observed in terms of completion times of interventions between in daytime and in dark scenario.

CONCLUSION: The operators who use NVGs have to be aware of that they can perform their tactic and medical activities without taking off the NVGs and without the requirement of an extra light source.

Keywords: Battlefield; darkness nighttime; emergency cricothyroidotomy; needle thoracostomy; night vision goggles; tube thoracostomy.

\section{INTRODUCTION}

An accurate and rapid prehospital response to life-threatening injuries is of great importance in both civil and military critical care. The loss of airway is the third leading cause of preventable death on the battlefield, ${ }^{[1,2]}$ and approximately $1 \%$ of emergency airway management cases require surgical airway opening. ${ }^{[3]}$ It has been reported that approximately $8 \%-15 \%$ of

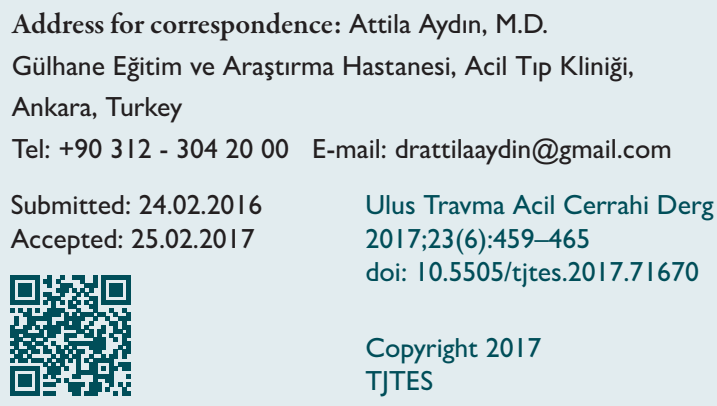

cases with airway obstruction, which develop due to penetrating maxillofacial or neck trauma, can be prevented by emergency cricothyroidotomy (EC) intervention. ${ }^{[4,5]}$ The success rate of the procedure varies from $62 \%$ to $100 \%$, depending on the operator. ${ }^{[6]} \mathrm{EC}$ is a life-saving procedure in the battlefield when airway interventions are ineffective or contraindicated. [7] EC is one of the last available options in difficult airway algorithms, when the state of "can't intubate, can't ventilate" exists. ${ }^{[6]}$ The survival rate of patients is low if this procedure is chosen. For patients with multiple and serious trauma, the early application of endotracheal intubation (ETI) and pleural drainage by the field team prior to hospitalization is associated with improved survival. Early responses in cases with tension pneumothorax (TPNX) are known to decrease mortality. ${ }^{[8]}$ When TPNX is determined in the field, needle thoracostomy (NT) has to be performed by a combat medic. According to the Advanced Trauma Life Support and Prehospital Trauma Life Support (PHTLS) guidelines, the first choice of treatment in TPNX is NT, which is applied in the second intercostal 
space (ICS) on the midclavicular line. ${ }^{[9,10]}$ This life-saving procedure transforms TPNX to simple pneumothorax prior to the application of chest tube thoracostomy (CTT), which is the definitive method of treatment. ${ }^{[2,1]}$ Although the failure rate is significant, it is extremely important for decreasing intrapleural pressure and gaining time to prepare for CTT. The success rate of procedures decreases on the battlefield due to the limited number of medical personnel, insufficient light, stress, noise, and ongoing hostilities. This situation becomes even more difficult, especially in nighttime conditions, due to light discipline. Due to this limitation, soldiers commonly use night vision goggles (NVG) during military operations conducted at nighttime. ${ }^{[12]}$ Although NVG are widely used, negligible research can be made in the dark with NVG in terms of the evaluation and care of the patients. To be able to effectively determine wound characteristics and perform the necessary interventions at night, vision and light restrictions can be mitigated with the use of tactical NVG. The study by Butler et al. ${ }^{[5]}$ describes a tragic example of the harm and damage that can be caused when an extra light source is used by paramedics/medics in the field of combat in the absence of NVG that we recommend. The method that should be used in a tactical light-restricted environment is still unknown. We considered that the success rate of EC, NT, and CTT management at night with NVG would be the same as that in daylight. The aim of the present study was to compare EC, NT, and CTT procedures, which would be managed in daylight and in a dark room with the aid of NVG, in terms of their success rates and administration duration. The aim of our study was to experimentally establish the feasibility of these life-saving interventions performed by combatant medical staff in a nighttime combat scenario with the aid of NVG.

\section{MATERIALS AND METHODS}

\section{Participants and Assessment Tool}

The GATA Ethics Committee approved the study (04/20I5-
786). In our study, all interventions were performed by experienced combatant medical staff, including 10 members who had been trained in Battlefield Advanced Trauma Life Support, which is a part of military tactical training. All members had $>5$ years of experience in tactical emergency medicine and tactical night operations with NVG. The operators were trained for EC, NT, and CTT procedures by specialists in military emergency medicine. This refreshment training (theoretical and practical), including anatomical landmarks and procedural tools, lasted for $60 \mathrm{~min}$ for each individual application. EC, NT, and CTT procedures were performed in the daytime by the naked eye in a bright room on previously prepared manikins/models (Fig. Ia-c). The second group of the same procedures was performed in a dark room, entirely insulated from light and with the aid of NVG (Fig. 2a-c). Interventions performed in daylight and in a dark room were randomized using www.randomizer.org, and all operators repeated each intervention twice. The study investigated the success and duration of the interventions. Operators graded the ease of intervention using a visual analog scale (VAS), with scores from I to 10: 10 for the most difficult interventions and I for the easiest interventions. These parameters were examined by specialists in military emergency medicine who were responsible for the study, and the results were recorded. During the interventions in a dark room, the operators and specialists in emergency medicine used monocular NVG (Aselsan 983A, Turkey-1995) (Fig. 3a).

\section{Phases of Manikins/Models Formation}

Needle Thoracostomy Manikin: A manikin (Simulaids Inc., Tension Pneumothorax Simulator, Woodstock, New York, USA) was used for this model (Fig. 3b).

Model of Emergency Cricothyroidotomy: The trachea was simulated with the air-draining tube of a mechanical ventilator $(2.5-\mathrm{cm}$ diameter). For fixation, the lateral walls of the simulated trachea were restricted with spume. Pieces of
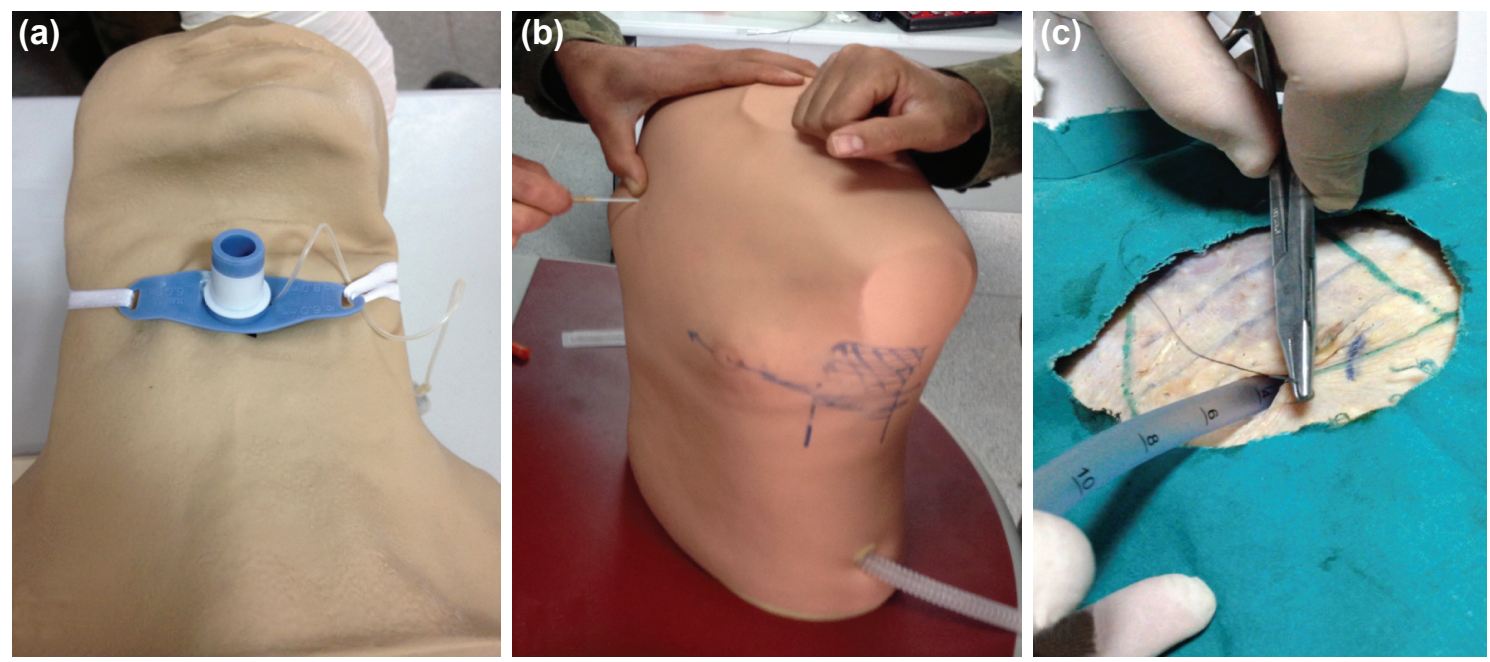

Figure 1. (a) Cricothyroidotomy intervention in daytime. (b) Needle thoracostomy intervention in daytime. (c) Chest tube thoracostomy intervention in daytime. 

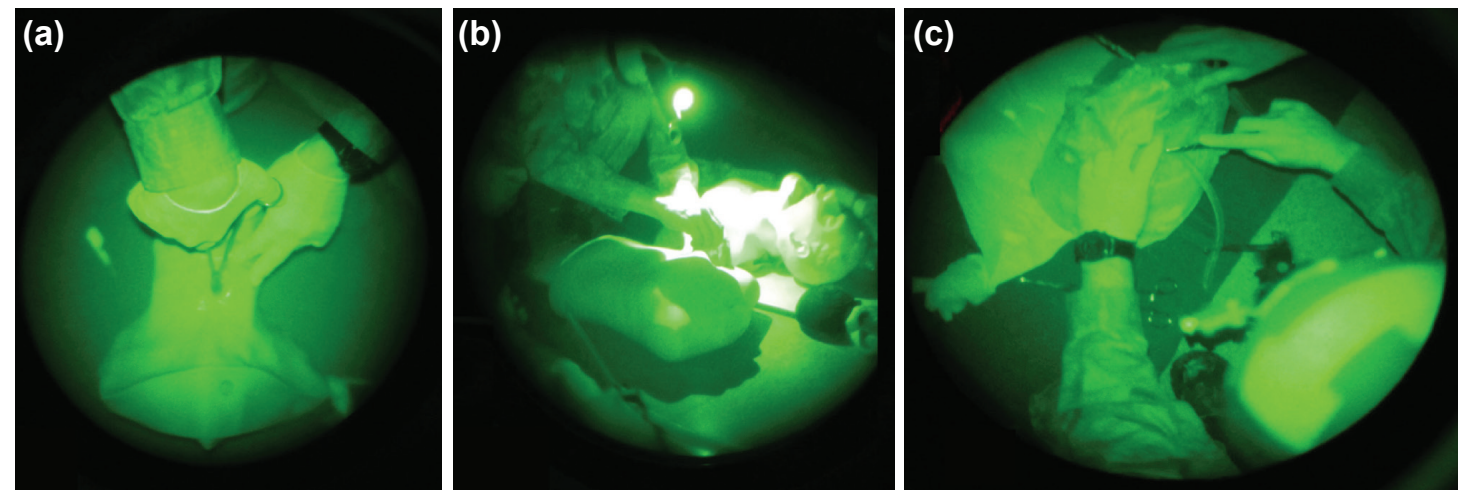

Figure 2. (a) Cricothyroidotomy intervention in nighttime with night vision goggle (NVG). (b) Needle thoracostomy intervention in nighttime with NVG. (c) Chest tube thoracostomy intervention in nighttime with NVG.

spume were placed on the trachea for simulating the thyroid and cricoid cartilage. Silk plaster was placed between these cartilages to form the cricothyroid membrane (CTM). Chicken meat was used to simulate subdermal tissues (Fig. $3 c$ ), and neck-like plastic moulage was used to simulate the skin (Fig. 3d).

Model of Tube Thoracostomy: The internal surface of a sheep thorax was covered with greased cooking paper to simulate the parietal pleura. For simulating the dermal and subdermal tissues, chicken meat and skin was used to cover the external surface of the sheep thorax (Fig. 3e).

\section{Procedure Steps and Criteria for Procedural Success}

Needle Thoracostomy: The first step is the determination by palpation of the second ICS by the operator. In the second step, a I6-G needle is placed on the second ICS midclavicular line by advancing it from the upper margin of the lower rib so that the sound of air is heard.

Emergency Cricothyroidotomy: The first step is the determination of the space to reach the CTM by the operator by palpating the thyroid and cricoid cartilage. In the second step, the CTM is palpated with one hand, whereas the other hand is fixing the trachea. In the third step, a vertical skin incision is made, down to the CTM using a \#I0 scalpel, and the CTM is reached by making a blunt dissection. In the fourth step, a horizontal incision is made on the CTM, and the opening is secured with a tracheal hook. The fifth step requires placing a tracheostomy cannula and expanding the cuff with $10 \mathrm{cc}$ of air. In the sixth step, the bag valve mask is tied, and bilateral lung ventilation and inflation are observed.

Tube Thoracostomy: The first step is the determination of the fourth or fifth ICS as the selected localization by the operator by palpating the related area. In the second step, the upper part of the lower rib is marked in the ICS where the intervention will be performed; this is followed by the consecutive local anesthesia procedures of the skin, subdermal tissue, and parietal pleura. In the third step, the simulated parietal pleura is reached by blunt dissection, following 4-5 $\mathrm{cm}$ of transverse incisions of the skin and subdermal tissue performed on the ICS; a "pop" sound must be heard to ensure that the parietal pleura in penetrated. In the fourth step, the site of the Heimlich valve to the chest tubing is clamped; the part that would be advanced to the thorax is placed in the pleural space with the aid of a curved Kelly clamp and from the area on which the blunt dissection is performed.
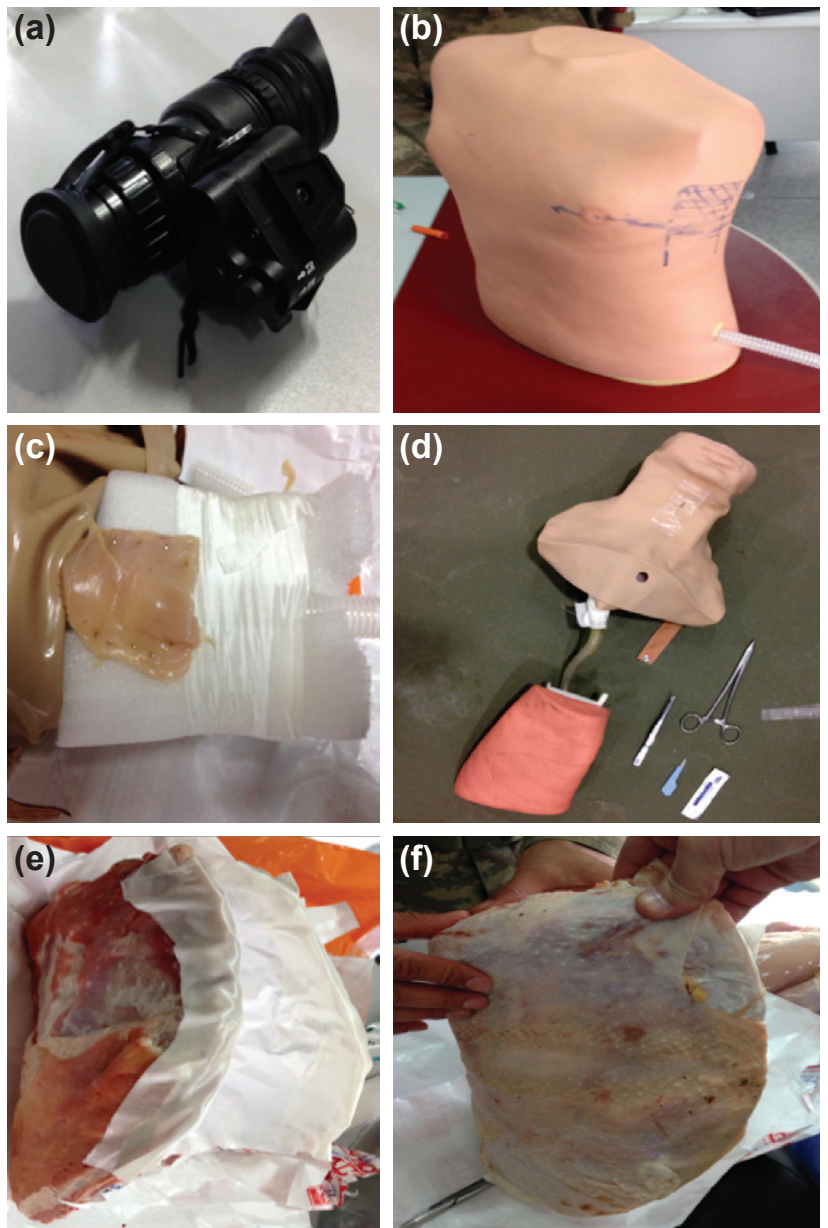

Figure 3. (a) Night Vision Goggle. (b) Model of Needle Thoracostomy. (c) Cricothyroidotomy neck model without plastic moulage. (d) Model of Emergency Cricothyroidotomy (Completed). (e) Model of Tube Thoracostomy (Completed). 
In the fourth step, the distal end of the chest tube is clamped. The proximal end of the chest tube is held with a curved Kelly clamp that is used to guide the chest tube through the tract. The chest tube is advanced to the pleural space from the dissection area. In the fifth step, a tube is connected to the Heimlich valve, and the clamp is extracted. In the sixth step, the tube is fixed with a skin suture.

\section{Sample Size}

We calculated that a minimum of eight patients in each group would be required to detect a 20-s difference between groups, assuming a standard deviation (SD) of $20 \mathrm{~s}$ with $80 \%$ power at an $\alpha$ level of 0.05 .

\section{Statistical Analysis}

Windows SPSS 22.0 (IBM statistics for Windows version 22, IBM Corporation, Armonk, New York, United States) was used for data analysis. Descriptive data were expressed as the median values and SD (minimum-maximum). The Wilcoxon test was used for comparing the two groups. Comparison of more than two groups was made using the Friedman test. Dual analyses were performed using the Bonferroni corrected Wilcoxon test when the Friedman test results revealed statistically significant differences. A $P$ value of $<0.005$ was considered as statistically significant.

\section{RESULTS}

Abbreviations for applications performed in daytime by the naked eye were expressed as "Day." Conversely, "NVG" was used for interventions using NVG (such as EC-D, NT-NVG, and CT-D).

\section{Difficulty Degree of Procedures}

Operators rated the difficulties in CTT-NVG and CTT-Day, and the CTT-Day and CTT-NVG VAS scores were 5.20 and 7.05, respectively; the difference was statistically significant $(p<0.007)$.

EC-NVG and EC-Day difficulty was compared, and EC-Day and EC-NVG VAS scores were 3.50 and 5.50, respectively; the difference was statistically significant $(p<0.005)$. NT-Day and NT- NVG VAS scores were the same, and no significant difference was observed in the difficulty between NT-NVG and NT-Day $(p=I .0)$ (Table I).

\section{Success Rate}

All interventions performed with the naked eye in the daytime and by NVG in the dark were found to be successful.

\section{Completion Time of Procedures}

Completion time of CTT-day was 304.930 s, of CTT-NVG was 307.860 s, of EC-Day was 97.42 s, of EC-NVG was 97.740 s, of NT-Day was 13.346 s, and of NT-NVG was I3.349 s. No significant difference was found between completion time of CTTDay and CTT-NVG, EC-Day and EC-NVG, and NT-Day and NT-NVG ( $p=0.799,0.878$, and 0.959, respectively) (Table 2).

\section{DISCUSSION}

The main finding of this study was that there was no difference in the success rate and completion time of CTT, EC, and NT between the daylight and NVG use in dark. The evaluation and management of the patient is highly dependent on good lighting conditions. Strict blackout discipline is extremely important for all military units, including allies. The type of

Table I. Difficulty degree of procedures (Visuel Analog Scale Scores)

\begin{tabular}{|c|c|c|c|c|c|}
\hline & \multicolumn{2}{|c|}{ Visuel Analog Scale Score-Day } & \multicolumn{2}{|c|}{ Visuel Analog Scale Score-NVG } & \multirow[t]{2}{*}{$\mathbf{p}^{\#}$} \\
\hline & Mean $\pm S D$ & Min-Max (s) & Mean $\pm S D$ & $\operatorname{Min}-\operatorname{Max}(\mathbf{s})$ & \\
\hline Chest tube thoracostomy & $5.20 \pm 0.5$ & $4.5-6$ & $7.05 \pm 1.1$ & $5-8.5$ & 0.007 \\
\hline Emergency cricothyroidotomy & $3.50 \pm 0.6$ & $2.5-4.5$ & $5.50 \pm 1$ & $4-7$ & 0.005 \\
\hline Needle thoracostomy & $1.40 \pm 0.5$ & $\mid-2$ & $1.40 \pm 0.4$ & $1-2$ & 1.0 \\
\hline
\end{tabular}

\#Wilcoxon Test. NVG: Night vision goggles; SD: Standard deviation.

Table 2. Completion time of procedures

\begin{tabular}{|c|c|c|c|c|c|}
\hline & \multicolumn{2}{|c|}{ Completion Time - Day } & \multicolumn{2}{|c|}{ Completion Time - NVG } & \multirow[t]{2}{*}{$\mathbf{p}^{\#}$} \\
\hline & Mean $\pm S D$ & Min-Max (s) & Mean $\pm S D$ & Min-Max (s) & \\
\hline Chest tube thoracostomy & $304.930 \pm 16.5$ & $291.1-334.9$ & $307.860 \pm 26.9$ & $280.9-372.9$ & 0.799 \\
\hline Emergency cricothyroidotomy & $97.420 \pm 24.8$ & $65.8-141.3$ & $97.740 \pm 23.2$ & $68.8-134.5$ & 0.878 \\
\hline Needle thoracostomy & $13.346 \pm 1.76$ & $10.9-16.1$ & $13.30 \pm 1.05$ & $10.9-14.6$ & 0.959 \\
\hline
\end{tabular}

\#Wilcoxon Test. NVG: Night vision goggles; SD: Standard deviation. 
response in a tactical light-restricted environment is still a matter of debate. ${ }^{[13,14]}$ To establish wound characteristics and for the related nighttime interventions, vision restrictions are avoided with the use of NVG.

In the randomized controlled trial study conducted by Brummer et al., ${ }^{[15]}$ Advanced Life Support techniques (ETI and intravenous line insertion) performed by the emergency medical professional in light and dark environments using NVG were compared with regard to the procedural success and velocity. The authors reported that NVG could be used in dark environment in these procedures, but successful results could be obtained in a longer time period compared with that by the conventional methods. They also reported that operators in the study did not have prior experience of NVG, and this could have contributed to this result. They suggested extensive training and routine practice for shortening the durations of applications. Maclntyre et al. ${ }^{[16]}$ showed the accomplishment of surgical airways in a dark environment with the use of NVG. Gellerfors et al. ${ }^{[2]}$ compared the time for successful ETI in manikins in a prospective, randomized, crossover study, and found the duration of ETI with NVG to be longer when compared with their application in daylight conditions. Schwartz and Charity ${ }^{[17]}$ compared intravenous insertion (IVI) procedures in the dark using NVG or a lowlevel Fingerlite light source. The success rate in the Fingerlite group was determined to be statistically higher. They considered that restricted depth perception, especially in monocular NVG, and refocusing the goggles manually, could contribute to this result. Contrary to these results, the success rates did not differ significantly in our study. We determined that interventions by the operators using NVG, were performed in a short time and with complete success. This result is due to the NVG experience of the operators, extensive training, and their routine practice in these procedures. Moreover, it was shown that depth perception affected the extent of success in the IVI and ETI but did not cause any restriction in the CTT, EC, and NT interventions. In conclusion, we established that interventions with NVG in a dark environment do not show any statistically significant differences, and therefore, experienced personnel can perform these interventions in the field without removing their NVG.

The following are the EC techniques used: the standard surgical method, tube-over-needle, wire-guided, and rapid four-step technique. On reviewing these methods in the literature, no consensus was found to exist on the superiority of a device or technique. Surgical cricothyroidotomy may be the preferred procedure for emergent airway management on the battlefield given the unique restrictions and considerations. ${ }^{[1,18,19]}$ The open technique via a vertical, midline incision is recommended. [6] A vertical, midline incision by a prehospital provider who is not a surgeon is recommended. The advantage of this incision is the better visualization of the anatomical structures, with possible enlarging when needed. In addition, the risk of bleeding is lower. ${ }^{[1]}$ EC model and procedural steps were designed according to the prehospital suggested vertical and midline incision. Rates of complications (bleeding, damage to airway structure, false placement, etc.) related to the procedure are high in the prehospital settings. ${ }^{[6]}$ Exposure, visualization, and direct palpation of the CTM are critical for combat medical personnel. When the CTM is visualized, the risk of subcutaneous and esophageal placements decreases. ${ }^{[20,21]}$ Although EC is a difficult procedure to perform unaided, the technique can be easily learned and recalled by minimally trained health care providers. [22] The success rate and velocity of application of EC varies, depending on the training models. The EC model designed in this present study was compatible with the theoretical and practical education related to the conventional EC techniques of the operators. Although the operators were experienced in NVG use with tactical aim, EC intervention with NVG was their first experience. Therefore, we think that the VAS scores of the interventions performed by NVG were higher than those of the intervention performed during the daytime.

Insufficient needle length, false catheter placement, catheter kinking, and luminal obstruction by blood clot are considered to be among the causes of unsuccessful NT. Chest wall thickness can affect the chances of successful NT. ${ }^{[23]}$ When second ICS midclavicular line and fourth ICS anterior axillary line were compared in terms of the chest wall thickness, 2ICS was found to be significantly thicker. According to the PHTLS guideline, interventions performed at the fourth/fifth ICS anterior axillary line (lateral approach) can be used alternatively. ${ }^{[23]}$ Givens et al. ${ }^{[24]}$ have used a 5-cm catheter via the $2 \mathrm{ICS}$, and the success rate was found to be approximately $75 \%$. When interventions were performed via the 2ICS with a catheter of $8 \mathrm{~cm}$ in length, interventions were found to be successful in more than $90 \%$ of the cases. ${ }^{[25]}$ The Committee of Tactical Combat Casualty Care (TCCC) recommends an 8-cm, I4-G needle for an NT. However, a long needle is also known to increase the risk of complications. ${ }^{[6]}$ Extensive bleeding due to large arterial injuries, cardiac tamponade, and neural injury are among these potential complications. ${ }^{[26]}$ A serious complication (left ventricular damage) may occur, especially in the lateral approach. ${ }^{[27]}$ Butler et al. and Rawlins et al. ${ }^{[28]}$ have reported injuries leading to life-threatening bleeding, following NT procedures performed via the 2ICS. We also used I4-G, 8-cm needles in our study, and participants were trained in interventions via the $2 \mathrm{ICS}$, as recommended by the TCCC. Nevertheless, complications could not be reported as the study was conducted with manikin/models. Possible death is prevented by the first therapeutic approach in the prehospital TPNX. However, decompression by needle may also be inefficient due to causes unrelated to the operator, such as a catheter of insufficient length, catheter kinking, and luminal obstruction by blood clot.

Although the first-line treatment option in prehospital TPNX has been accepted as NT, we suggest that operators will mandatorily apply CTT in the battlefield in the future, in the event of possible failure or irresponsiveness to therapy. Therefore, 
we tested the skills of the operators for CTT intervention both in the daytime and at night.

Dominguez et al. ${ }^{[29]}$ have reported the essentials of CTT as the clinical signs of a stable patient and the evaluation of the intrathoracic air and blood by chest X-ray and thorax CT, rather than the prehospital application of NT alone. Considering operation under field conditions, together with the absence of the appropriate visualization methods for a casualty requiring $\mathrm{CT}$ and the possible length of time it can take to evacuate the wounded, what should the treatment of choice be next to NT for casualties not responding to NT and showing slowly deteriorating clinical signs? Prehospital chest drainage was demonstrated to improve the survival of severe trauma patients. ${ }^{[8]}$ The authors claimed that simple thoracostomy is safe and effective in prehospital trauma management and that the procedure requires trained and experienced operators. ${ }^{[30]}$ In this case, CTT would be the last choice of treatment. Combat medics generally respond to casualties on the operating field. However, regarding this procedure, combat medics are restricted in terms of their training, skill, and legal authority. When the options are either the possibility of preventing the death of a casualty or restrictive factors in the field resulting in casualties not responding to NT, the loss of the casualty would become a matter of dispute. In a prospective study, Schmidt et al. ${ }^{[31]}$ investigated 624 consecutive patients with chest injuries and reported that prehospital CTT is safe, effective, and associated with low morbidity. We believe that CTT is an effective procedure for the severely injured and that it simplifies treatment in prehospital care while keeping scene times to a minimum. In future cases considered for CTT, with the use of NVG, it would be possible to perform this procedure in the operating field in the dark. In our study, all participant operators successfully completed CTT interventions with NVG. When compared with those conducted in the daytime, the duration of the CTT procedures conducted in nighttime conditions did not show significant difference. This projection provides immense support for future CTT applications in the field. The findings of this study, in terms of VAS scores for CTT and the duration necessary for completion of the procedure, confirmed that CTT can be successfully applied in prehospital systems.

According to the VAS scale results, the CTT-NVG and ECNVG interventions in the CTT and EC procedures were difficult for the operators. This result was considered to be due to the operators' lack of experience in these procedures using NVG. Because NT intervention is more straightforward and has fewer procedural steps than CTT and EC interventions, no difference was observed between NT-Day and NT-NVG. This result demonstrated that training for the interventions performed using NVG should be regularly repeated. Our study has several important limitations. The first limitation is the use of models instead of real patients in our study. Use of the organs or tissues of dead animals or the combination of organic and plastic materials may be more useful in these interventions instead of using the manikins alone, which are produced from plastic materials. We consider that procedural duration and success might vary in actual conditions due to factors, such as bleeding, foreign bodies, battlefield situations, and noise, which can be evaluated as a second limitation. The study has not been tested in the dark in terms of tactical considerations and security, which is the third limitation. The fourth limitation is the relatively small number of sampling in our study, and to our knowledge, a study with which our results can be compared is not available in the literature.

\section{Conclusion}

Medical providers must acquire knowledge and experience about the signs, diagnosis, and treatment of TPNX and airway obstruction. They must be able to perform these types of life-saving procedures (EC, NT, and CTT) related to preventable causes of death and undergo frequent training. Training with NVG in a dark room performed on models and manikins may also contribute to the procedural success and duration of these life-saving interventions performed in the daytime and may also help enhance the operators' skills at night. Operators who use NVG have to be aware that they can perform their tactical and medical activities without taking off their NVG and without the need for extra light sources when they have to perform interventions for EC, NT, and CTT in the dark. In addition, we consider that NVG use in EC, NT, and CTT interventions performed by paramedics/medics who work as members of humanitarian aid institutions and perform first aid in the dark in chaotic or disorganized circumstances can offer safety both for the providers of first aid and the wounded individuals. Future studies could include a larger number of participants and different types of NVG.

\section{Conflict of interest: None declared.}

\section{REFERENCES}

1. Mabry RL, Edens JW, Pearse L, Kelly JF, Harke H. Fatal airway injuries during Operation Enduring Freedom and Operation Iraqi Freedom. Prehosp Emerg Care 2010;14:272-7. [CrossRef]

2. Proctor MD, Campbell-Wynn L. Effectiveness, usability, and acceptability of haptic-enabled virtual reality and mannequin modality simulators for surgical cricothyroidotomy. Mil Med 2014;179:260-4. [CrossRef]

3. Quick JA, MacIntyre AD, Barnes SL. Emergent surgical airway: comparison of the three-step method and conventional cricothyroidotomy utilizing high-fidelity simulation. J Emerg Med 2014;46:304-7. [CrossRef]

4. Kelly JF, Ritenour AE, McLaughlin DF, Bagg KA, Apodaca AN, Mallak CT, et al. Injury severity and causes of death from Operation Iraqi Freedom and Operation Enduring Freedom: 2003-2004 versus 2006. J Trauma 2008;64(2 Suppl):S21-6. [CrossRef]

5. Butler FK Jr, Holcomb JB, Giebner SD, McSwain NE, Bagian J. Tactical combat casualty care 2007: evolving concepts and battlefield experience. Mil Med 2007;172:1-19. [CrossRef]

6. Mabry R, Frankfurt A, Kharod C, Butler F. Emergency Cricothyroidotomy in Tactical Combat Casualty Care. J Spec Oper Med 2015;15:11-9.

7. Melchiors J, Todsen T, Nilsson P, Wennervaldt K, Charabi B, Bøttger $M$, et al. Preparing for emergency: a valid, reliable assessment tool for emergency cricothyroidotomy skills. Otolaryngol Head Neck Surg 
2015;152:260-5. [CrossRef]

8. Schmidt U, Frame SB, Nerlich ML, Rowe DW, Enderson BL, Maull $\mathrm{KI}$, et al. On-scene helicopter transport of patients with multiple injuries-comparison of a German and an American system. J Trauma 1992;33:548-53. [CrossRef]

9. Bach PT, Sølling C. Failed needle decompression of bilateral spontaneous tension pneumothorax. Acta Anaesthesiol Scand 2015;59:807-10.

10. Ng C, Tsung JW. Point-of-care ultrasound for assisting in needle aspiration of spontaneous pneumothorax in the pediatric ED: a case series. Am J Emerg Med 2014;32:488. [CrossRef]

11. Kesieme EB, Dongo A, Ezemba N, Irekpita E, Jebbin N, Kesieme C. Tube thoracostomy: complications and its management. Pulm Med 2012;256878.

12. Gellerfors M, Svensén C, Linde J, Lossius HM, Gryth D. Endotracheal Intubation With and Without Night Vision Goggles in a Helicopter and Emergency Room Setting: A Manikin Study. Mil Med 2015;180:100610. [CrossRef]

13. Bozeman WP, Eastman ER. Tactical EMS: an emerging opportunity in graduate medical education. Prehosp Emerg Care 2002;6:322-4. [CrossRef]

14. Rinnert KJ, Hall WL. Tactical emergency medical support. Emerg Med Clin North Am 2002;20:929-52. [CrossRef]

15. Brummer S, Dickinson ET, Shofer FS, McCans JP, Mechem CC. Effect of night vision goggles on performance of advanced life support skills by emergency personnel. Mil Med 2006;171:280-2. [CrossRef]

16. MacIntyre A, Markarian MK, Carrison D, Coates J, Kuhls D, Fildes JJ. Three-step emergency cricothyroidotomy. Mil Med 2007;172:1228-30.

17. Schwartz RB, Charity BM. Use of night vision goggles and low-level light source in obtaining intravenous access in tactical conditions of darkness. Mil Med 2001;166:982-3.

18. Sebesta J. Special lessons learned from Iraq. Surg Clin North Am 2006;86:711-26. [CrossRef]

19. Adams BD, Cuniowski PA, Muck A, De Lorenzo RA. Registry of emergency airways arriving at combat hospitals. J Trauma 2008;64:1548-54.

20. Yıldız G, Göksu E, Şenfer A, Kaplan A. Comparison of ultrasonography and surface landmarks in detecting the localization for cricothyroidotomy. Am J Emerg Med 2016;34:254-6. [CrossRef]
21. Feng Y, Deng H, Liu X, Xu G, Huang Z, Yan B, et al. A new strategy for difficult airway management with visual needle cricothyroidotomy: a manikin study. Am J Emerg Med 2014;32:1391-4. [CrossRef]

22. Mabry RL, Nichols MC, Shiner DC, Bolleter S, Frankfurt A. A comparison of two open surgical cricothyroidotomy techniques by military medics using a cadaver model. Ann Emerg Med 2014;63:1-5. [CrossRef]

23. Kolinsky DC, Moy HP. Evidence-based EMS: needle decompression. Recent data may cause us to reconsider our preferred thoracostomy location. EMS World 2015;44:28-30.

24. Givens ML, Ayotte K, Manifold C. Needle thoracostomy: implications of computed tomography chest wall thickness. Acad Emerg Med 2004;11:211-3. [CrossRef]

25. Chang SJ, Ross SW, Kiefer DJ, Anderson WE, Rogers AT, Sing RF, et al. Evaluation of $8.0-\mathrm{cm}$ needle at the fourth anterior axillary line for needle chest decompression of tension pneumothorax. J Trauma Acute Care Surg 2014;76:1029-34. [CrossRef]

26. Butler KL, Best IM, Weaver WL, Bumpers HL. Pulmonary artery injury and cardiac tamponade after needle decompression of a suspected tension pneumothorax. J Trauma 2003;54:610-1. [CrossRef]

27. Wernick B, Hon HH, Mubang RN, Cipriano A, Hughes R, Rankin DD, et al. Complications of needle thoracostomy: A comprehensive clinical review. Int J Crit Illn Inj Sci 2015;5:160-9. [CrossRef]

28. Rawlins R, Brown KM, Carr CS, Cameron CR. Life threatening haemorrhage after anterior needle aspiration of pneumothoraces. A role for lateral needle aspiration in emergency decompression of spontaneous pneumothorax. Emerg Med J 2003;20:383-4. [CrossRef]

29. Dominguez KM, Ekeh AP, Tchorz KM, Woods RJ, Walusimbi MS, Saxe $\mathrm{JM}$, et al. Is routine tube thoracostomy necessary after prehospital needle decompression for tension pneumothorax? Am J Surg 2013;205:329-32.

30. Massarutti D, Trillò G, Berlot G, Tomasini A, Bacer B, D'Orlando L, et al. Simple thoracostomy in prehospital trauma management is safe and effective: a 2-year experience by helicopter emergency medical crews. Eur J Emerg Med 2006;13:276-80. [CrossRef]

31. Schmidt U, Stalp M, Gerich T, Blauth M, Maull KI, Tscherne H. Chest tube decompression of blunt chest injuries by physicians in the field: effectiveness and complications. J Trauma 1998;44:98-101. [CrossRef]

\title{
DENEYSEL ÇALIŞMA - ÖZET
}

\section{Savaş alanında hayat kurtarıcı prosedürlere yeni bir bakış: Gece görüş gözlükleri ile acil krikotroidotomi, iğne torakostomi ve göğüs tüp torakostomi}

\section{Dr. Sedat Bilge, ${ }^{1}$ Dr. Attila Aydın, ${ }^{1}$ Dr. Meltem Bilge, ${ }^{3}$ Dr. Cemile Aydın, ${ }^{4}$ Dr. Erdem Çevik, ${ }^{2}$ Dr. Mehmet Eryılmaz ${ }^{1}$}

\author{
${ }^{1}$ Gülhane Eğitim ve Araștırma Hastanesi, Acil Tıp Kliniği, Ankara \\ ${ }^{2}$ Sultan Abdülhamit Eğitim ve Araştırma Hastanesi, Acil Tıp Kliniği, İstanbul \\ ${ }^{3}$ Dışkapı Eğitim ve Araştırma Hastanesi, Anesteziyoloji ve Reanimasyon Kliniği, Ankara \\ ${ }^{4}$ Ankara Etimesgut Devlet Hastanesi, İç Hastalıkları Kliniği, Ankara
}

AMAÇ: Ağır ve çoklu travma hastalarında, hayat kurtarıcı prosedürlerin erken uygulanması artmış sağ kalım ile ilişkilidir. Gece yapılan savaş senaryosunda bu hayat kurtarıı girişimlerin gece görüş gözlüğü (GGG) yardımıyla uygulanabilirliğini deneysel olarak saptamaya çalıştık.

GEREÇ VE YÖNTEM: Göğüs tüp torakostomi (GTT), acil krikotroidotomi (AK) ve iğne torakostomi (IT) girişimleri 10 adet askeri sağlık personeli tarafından gerçekleştirildi. Çalışmada girişimlerin başarı ve süreleri incelendi. Prosedürler, hazırlanan maket/model üzerinde gündüz aydınlık odada ve GGG yardımı ile karanlık odada yaptııılı. Operatörler girişimlerin kolaylığını derecelendirdi.

BULGULAR: Tüm girişimler başarlı bulundu. Operatörler, gece yapılan GTT ve AK girişimlerini gündüz saatlerinde yapılan girişimlere göre zor buldu $(p<0.05)$. İğne torakostomi grupları arasında zorluk açısından anlamlı fark yoktu. Girişimlerin tamamlanma süreleri açısından karşılaştırıldığında, gündüz ve gece senaryoları arasında fark yoktu.

TARTIŞMA: Gece görüş gözlüğü kullanan operatörler, taktik ve medikal aktivitelerini yaparken gece görüş gözlüklerini çıkarmalarına ve ekstra ışık kaynağı kullanmalarına gerek olmadığı konusunda uyanık olmalıdırlar.

Anahtar sözcükler: Acil krikotroidotomi; gece görüş gözlükleri; iğne torakostomi; karanlık; savaş alanı; tüp torakostomi.

Ulus Travma Acil Cerrahi Derg 2017;23(6):459-465 doi: 10.5505/tjtes.2017.71670 